\title{
Estudio de los paralelos iconográficos en las emisiones monetales de la Córdoba romana
}

\author{
Miguel Ángel Cebrián Sánchez *
}

\begin{abstract}
RESUMEN ${ }^{+}$ABSTRACT
Este trabajo pretende realizar un estudio comparativo de las imágenes monetales que se acuñaron en las emisiones numismáticas de la Córdoba romana. Las demás cecas hispanas y extrapenínsulares que comparten tipos con Colonia Patricia

Corduba y que son el referente iconográfico ideal para poder comprender el significado de estas monedas que parecen estar vinculadas a las corrientes políticas de los estertores de la República romana $y$ del comienzo del principado augusteo.

This work seeks to carry out a comparative study about the monetary images which were coined in the numismatic issues of the Roman Cordoba. The rest Spanish and extrapeninsular royal mints that shave types with Colonia Patricia Corduba are the ideal iconographic reference in order to understand the meaning of these coins that seems to be related to the politic currents of the death rattles of the Roman Republic and of the beginning of Augusteam princedom.
\end{abstract}

Seminario de Arqueología de la Universidad de Córdoba.

1 Un estudio más completo, sobre este asunto, lo podemos encontrar en nuestra Memoria de Licenciatura (inédita): La tipología de las monedas y la fundación de la Colonia Patricia, dirigida por la Profesora Dra. D. ${ }^{a}$ Pilar León Alonso, Catedrática de Arqueología de la Universidad de Córdoba. El aparato gráfico procede de: CHAVES, F. (1977) La Córdoba hispano-romana y sus monedas, Córdoba. Calicó, X. \& F. (1991) Los denarios romanos anteriores a J. C., Barcelona. Agredecemos su generosidad. 


\section{INTRODUCCIÓN}

En el presente articulo procedemos a analizar los diferentes paralelos iconográficos de las series numismáticas de la Córdoba romana. Para ello hemos dividido las emisiones en función de su cronología y entorno histórico, dándonos el siguiente resultado: $1 .^{\circ}$ Momento, moneda local del año 48 a. C. con leyenda CORDUBA; $2 .^{\circ}$ Momento, acuñaciones extraordinarias de los años 46-45 a. C. realizadas por los partidarios de Pompeyo el Grande para el pago de la soldada; $3 .^{\circ}$ Momento, amonedaciones, supuestamente patricienses, de los años 26-16 a. C. destinadas, en parte, al pago del ejercito romano acuartelado en el limes germano ${ }^{2 ;} 4 .^{\circ}$ Momento, serie local augustea emitida entre los años 13-11 a. C. Con leyenda $C O-$ LONIA PATRICIA.

La importancia que adquieren los paralelos en el estudio de los tipos de cuños utilizados en Corduba-Colonia Patricia está fuera de duda, puesto que la ceca de Córdoba en época romana no puede entenderse sin una revisión de los motivos empleados en las demás cecas de Hispania. La visión de conjunto ${ }^{3}$ de cecas de la Península lbérica, junto con una revisión de la moneda romana para el tercer y cuarto Momento, es lo que nos permite apreciar con mayor precisión el conjunto de ideas, prestamos tipológicos ${ }^{4}$ e imágenes que muestran a través de las monedas las demás ciudades que compartieron, en la misma época, con esta ciudad el derecho de acuñación.

\section{PRIMER MOMENTO}

Para las monedas de la Córdoba romana, a veces, es difícil encontrar paralelos en cecas peninsulares. Corduba posee en sus tipos republicanos locales - Cabeza femenina (Venus), Personaje juvenil alado (Cupido) - una diferencia de tipos que no se da en las acuñaciones de la provincia Ulterior. La razón principal de no ver parecidos formales en la Ulterior (ni en la Citerior) radica en una diferente visión de las monedas, es decir, mientras las monedas ibero-romanas, coetáneas en el tiempo, presentaban tipos deudores de los viejos motivos iconográficos iberos y púnicos - para usuarios

2 Para este dato nos parece oportuna la hipótesis de: GARCíA-BeLLIDO, M.aP. (1996) «Las monedas hispanas de los campamentos del Lippe ¿Legio Prima (antes Augusta) en Oberaden?», Boreas, band 19, (247-260).

3 VV. AA. (1997) Historia monetaria de Hispania Antigua, Madrid.

4 Rebuffat, F. (1996) La monnaie dans l'Antiquité, París. 
indígenas--, las monedas con leyenda CORDUBA son herederas de la vieja tradición iconográfica romana republicana; como también lo fueron los tipos acuñados en Malaca ${ }^{5}$ donde encontramos leyendas fenicias y métrica diferente a la utilizada en Corduba, lo que no es impedimento para producir unos tipos de tradición republicana romana con un aire local muy particular. A nuestro juicio las piezas locales cordobesas republicanas tienen como paralelo formal los denarios republicanos acuñados por César -en cecas galas- (RRC, 468-1), en los que se incluyen los mismos tipos que en los cuadrantes cordobeses. Son varias los monetales ${ }^{6}$ que acuñan en la ceca de Roma la cabeza de la diosa Venus, siendo este tipo muy corriente en los anversos de la familia lulia en la segunda mitad del siglo I a. C. y estrechamente ligados a los tipos cordubenses por la carga propagandística que les une a las monedas emitidas por César en la Galia ?

El problema principal que presentan los paralelos romanos, antes comentados en estas acuñaciones, es que se tratan en todos los casos de denarios, mientras que los cordobeses son cuadrantes. Esta diferencia hace que haya una razón política para que no se acuñaran valores altos

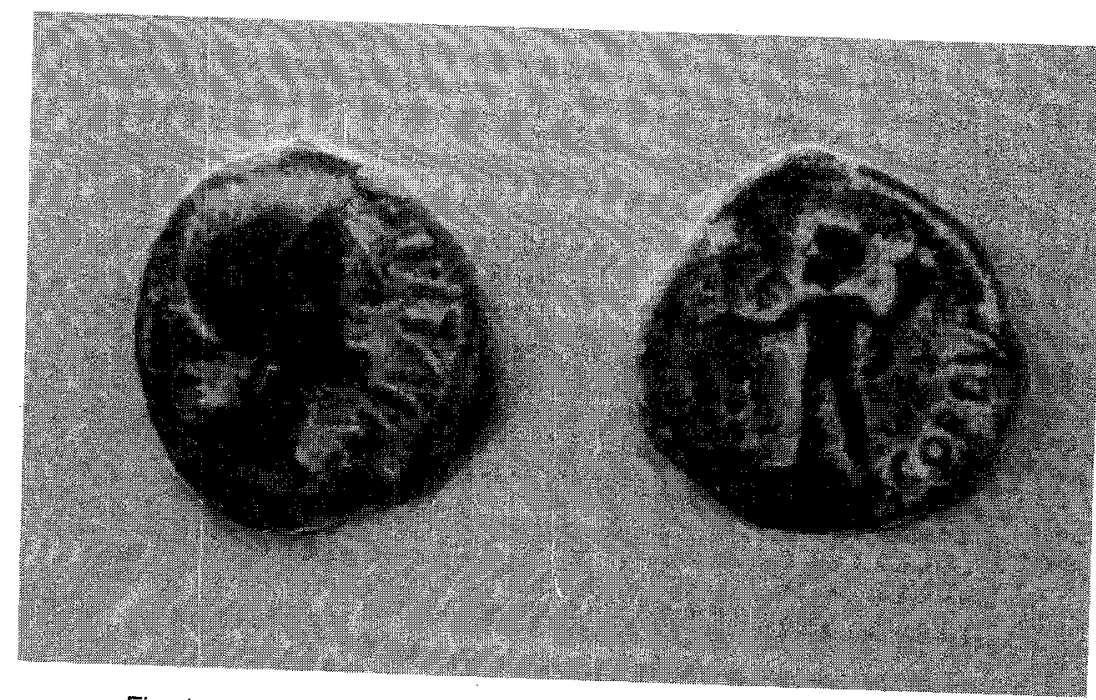

Fig. 1. 1. ${ }^{\circ}$ Momento: monedas con leyenda CORDUBA (número 1).

\footnotetext{
Ver: VIVES, A. (1926) La moneda hispánica, Madrid (Tomo III, pág. 27-28).

of the Roman Republic, London (sere Venus encontramos en: SYDENHAMM E.A. (1952) The coinage

7 García-Bellido, M. ${ }^{\text {a }}$ P. (1992) «La moneda, $44, n .^{\circ} 1.008 ; 42, n .{ }^{\circ} 1.014 ; 34, n .^{\circ} 739$ ).

ibérica a través de la imagen, Madrid, (39-79).
} 
paralelizables con los cuños cordubenses. El hecho puede deberse a que la provincia Ulterior conservó la libertad de elegir en sus monedas tipos, lengua de las leyendas y valores, pero perdió el derecho a acuñar oro y plata desde época catoniana, aun cuando las mejores minas de plata se encontraban en ésta provincia (Cástulo, Sierra Morena y la zona de Cartagonova). Las piezas cordobesas nacieron, dentro de la ciudad, con modelos traídos por las modas impuestas a la sombra de las victorias de César y dentro de la vinculación de su estirpe con la propia diosa Venus. Otra causa, ajena a la anterior, es el problema de falta de numerario, en valores bajos, durante todo el siglo । a. C., hecho éste endémico y que afectó a la Ulterior.

El personaje infantil del reverso de estas piezas puede jugar un doble significado; por una parte el abridor penso en el préstamo de imagen que supondría el tipo de Cúpido -en acuñaciones romanas (RRC, 468-1) acompañando a la diosa, perfectamente reconocido por las elites romanas y locales, así como por el ejercito romano. Del mismo modo la visión de este personaje podría ser considerado por las clases populares como un genio protector de la ciudad. Como podemos ver una imagen prestada nos puede dar significados diferentes, en función de los usuarios. Aunque la primera connotación vino, como hemos dicho, tomada de un nivel iconográfico difícil de comprender para una gran parte de la población que usaba cotidianamente estas monedas de poco valor.

La idea principal para comprender las imágenes de estas monedas viene marcada por la utilización prestada de los tipos cesarianos de la Galia (RRC; 452-2, 458-1, 468-1). Por ello pensamos que esta acuñación, primigenia de la ceca cordobesa local, responde en cuanto a sus paralelos a una visión cosmopolita, que la ciudad poseía frente a las demás cecas hispanas del momento. La identificación de las imágenes reproducidas, coetáneas en el tiempo, son el exponente de la rápida asimilación de los hechos políticos ocurridos en el Occidente del imperio y su posterior incorporación iconográfica a las monedas cordubenses.

\section{SEGUNDO MOMENTO}

Las acuñaciones pompeyanas atribuidas al taller cordobés no encuentran paralelos en el resto de las cecas hispanas. En estos cuños hay que buscar paradigmas en el marco de las acuñaciones militares de Roma realizadas en función de los movimientos del ejercito en las guerras acaecidas entre César y Pompeyo el Grande o en arquetipos propios de las viejas acuñaciones romanas republicanas de los siglos III-II a. C. 
Para el retrato de Pompeyo que encontramos en el anverso de la moneda $n .^{\circ} 2$ tenemos que hacer referencia a la fuerte tradición retratística griega posterior a Alejandro el Grande; mezclado todo con el propio carácter cosmopolita que había tomado el propio Pompeyo al que no eran ajenos sus seguidores. Este es el caso del procuestor M. Minatio Sabino ${ }^{8}$, que no dudó en colocar la imagen de quien lideraba la causa republicana frente a César. Hemos de tener presente para este retrato la costumbre de la retratística monetal romana en época de los triunviratos, donde las eclécticas imágenes de los dioses y alegorías de los anversos dejan paso a las personas que dirigen un estado que ya dominaba extensos territorios en torno al Mediterráneo. Este es el momento en que los retratos de personas vivas se dan a conocer entre las clases populares, el reconocer los rostros de los líderes políticos se convierte en una buena baza propagandística, por ello no debemos buscar paralelos más alejados en el tiempo y en el espacio que estas acuñaciones de finales de la República, en las cuales Pompeyo es uno de los ejemplos más tempranos, junto a Ahenobarbo, Bruto, Labieno..., que también aparecen en estos momentos. El caso de poder contar con retratos monetales en Corduba es un hecho lógico, ante los acontecimientos políticos que se desarrollaban en Hispania: la lucha entre César y Pompeyo.

El propio reverso de la moneda anterior muestra una escena de bienvenida que tiene paralelos en la Guerra Social ${ }^{9}$ acaecida a principios del siglo I a. C. en Italia (RRC, 470/1a). Otorgar a este motivo otros paralelos sería un tanto aventurado, ya que aunque las escenas entre dos personajes son corrientes entre las acuñaciones romanas en todos los tiempos, esta imagen refleja el hecho concreto de la llegada del hijo de Pompeyo a la Ulterior acaecido en la realidad - no es una escena mitológica que tanto abundan en las monedas romanas-. Tras ello debemos entender el positivo recibimiento a los hijos de Pompeyo en la provincia Ulterior por parte de las élites locales ${ }^{10}$.

A la hora de reconocer ejemplos en el anverso de la moneda acuñada por M. Poblicius (RRC, 469/1a), que presenta la cabeza galeada de Roma $\left(n .^{\circ} 3\right.$ ), es más que tentador dar un pequeño recorrido por una imagen que era literalmente adorada por la ciudadanía romana y que está presente en la inmensa mayoría de las acuñaciones republicanas. Esta oportunidad que da la ceca de Corduba para analizar este tipo impone el re-

8 ZehnNAKer, H. (1973) Moneta. Recherches sur l'organisation et l'art des émissions monétaires de la République Romaine, Rome, (1.008-1.009).

9 ZeHNNAKER, H., op. cit. nota 8, pág. 556.

10 Curchin, L. (1990) The roman local magistrates of Roman Spain, Toronto. 
cordar la idea de tipo parlante, que existía en la ceca griega de Atenas entre Atenea y la ciudad. En Roma se presenta la misma imagen, una diosa que recibe el nombre de la misma ciudad. Los mismos habitantes romanos sentían una intima relación entre su vida y la ciudad donde vivían, por ello aparte de templos a la diosa Roma se le reservó a la deidad el anverso de las monedas durante todo el periodo republicano. El encontrar esta deidad en las monedas pompeyanas es sintomático de la vinculación propagandística que los Pompeyo quieren hacer de su causa, utilizando para ello una imagen que ya en esa época debió de reconocerse como un sagrado arcaísmo iconográfico.

Para el reverso de la moneda se emplea otra escena en conjunción con el anverso antes comentado. Se trata de una entrega simbólica de la victoria militar que encuentra paralelos en las acuñaciones del siglo । a. C., en piezas donde podemos observar diferentes actos de entrega: coronas, cuernos de la abundancia... (RRC, 329/1a; RRC, 403/1). Todas estas imágenes tratan de evocar instantáneamente un momento simbólico o un acto

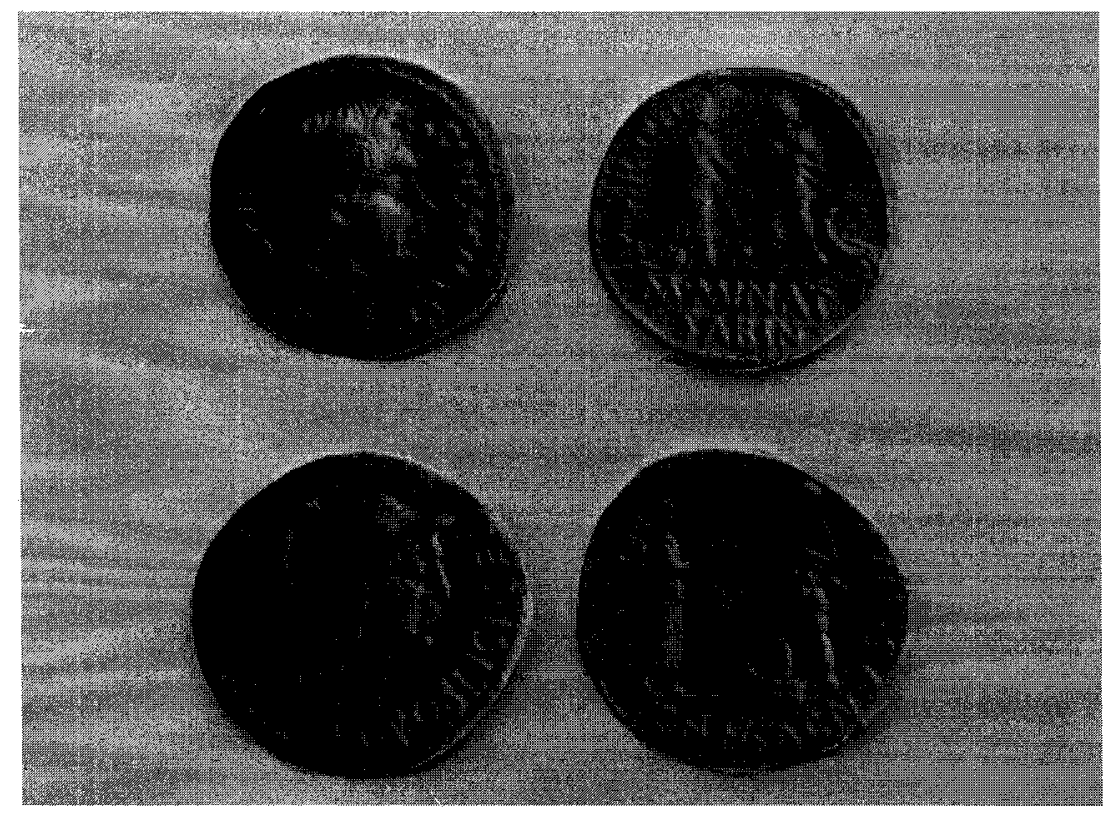

Fig. 2. 2. ${ }^{\circ}$ Momento: emisiones extraordinarias pompeyanas (números 2 y 3 ). Mainz.

11 La iconografia de la Victoria en Roma la recoge: HöLSCHER, T. (1967) Victoria romana, 
de entrega -en este caso de una victoria ${ }^{11}$-, sin encontrar ningún reparo en mezclar personajes reales con divinidades y alegorias. Esto es el resultado del triunfo, de la sabia mezcla, del buen hacer griego - helenístico- en la numismática y el carácter romano, eminentemente didáctico y propagandístico.

En este momento podemos ver como los paralelos más acertados para las monedas de la Córdoba republicana nacen de una visión cosmopolita de la ciudad, que buscaba a todas luces la importancia de su razón de ser, vinculándose a los acontecimientos políticos de la Urbs. Por estas imágenes nos hacemos a la idea de las intenciones de ascenso que la ciudad pretendió. Las causas, exógenas en su mayoría, de las acuñaciones republicanas en la ciudad se vieron envueltas en unos motivos que fueran comprensibles para las elites y los ejércitos romanos que para las clases populares indígenas. Pero este sacrificio permitió que la circulación de estas monedas fuera comprensible desde la distancia —donde también eran conocidas imágenes parecidas-, por una causa esencial: La ciudad era reconocida por un grado de civilización que era propio de los tipos "civilizados" de sus monedas, y que era raro de encontrar en las demás acuñaciones de la Península Ibérica.

\section{TERCER MOMENTO}

Las acuñaciones imperiales augusteas, supuestamente patricienses, producidas en su mayoría en esta ciudad gozaron de un esquema iconográfico programado desde la Urbs ${ }^{12}$. Dicho esquema contó con dos paralelos importantes en la Península Ibérica: Emérita y Caesaraugusta. Para las acuñaciones de Emérita (Vives, T. IV, pág. 61-62 (1-18) hay que destacar que fueron monedas en plata, que se acuñaron - como las patricienses- para el pago de los ejércitos acuartelados en el Occidente del imperio ${ }^{13}$ y que reservan los anversos a la imagen de Augusto; por contra, estas monedas incluyen el nombre del legado imperial - $P$. Carisius- que las mandó acuñar, y unos tipos de reverso diferentes a los patricienses, por su carácter a todas luces localistas (armas ibéricas, Puertas torreadas...). Por la inclusión en los reversos de la cabeza de Augusto es por lo

12 Nos remitimos a los aspectos de imágenes monetales de la obra: ZANKER, P. (1992) Augusto y el poder de la imágenes, Madrid.

13 Op. cit., nota 2, pág. 252. También nos remitimos, en cuanto a la posible circulación de estas piezas, a: CEBRIÁN, M. A. (1998) «Acuñaciones augusteas en plata en el Museo Arqueológico y Etnológico de Córdoba (MAECo.)", Actas del X Congreso Nacional de Numismática, (en prensa). 
que estas acuñaciones tienen semejanzas a las piezas aquí estudiadas. En los retratos podemos reconocer unas ideas muy semejantes a la hora de trabajarlos y que sin duda corresponderían a obras de un mismo maestro abridor de cuños y de su escuela.

En lo que respecta a las monedas imperiales posiblemente acuñadas en Caesaraugusta, gozan de las mismas características que las patricienses. Estas son obras debidas a la necesidad de numerario para las guerras Cántabras y con motivos que fueron de vanguardia propagandística en este momento afines a las dos cecas - los homenajes del año 27 a. C.- Las acuñaciones de esta ceca guardan tan estrecha relación iconográfica, que a la hora de diferenciarlas se produce un verdadero caos. El hecho viene determinado por el empleo en estas dos cecas -e incluso en Lugdunun y Nemausus - de los mismos cuños o de la misma mano Tan sutil diferencia se encuentra en piezas como las $n .^{\circ} 4$ y 10 de nuestro catálogo, que pudieron ser acuñadas en ambas cecas sin una definitiva opinión que aúne este problema.

Los elementos que comparten las cecas patriciense y caesaragustana son: cabeza de Augusto tipo Actium - como en Emérita-, el clipeo de la Virtud, árboles de laurel y victoria coronando un escudo. Rememoramos

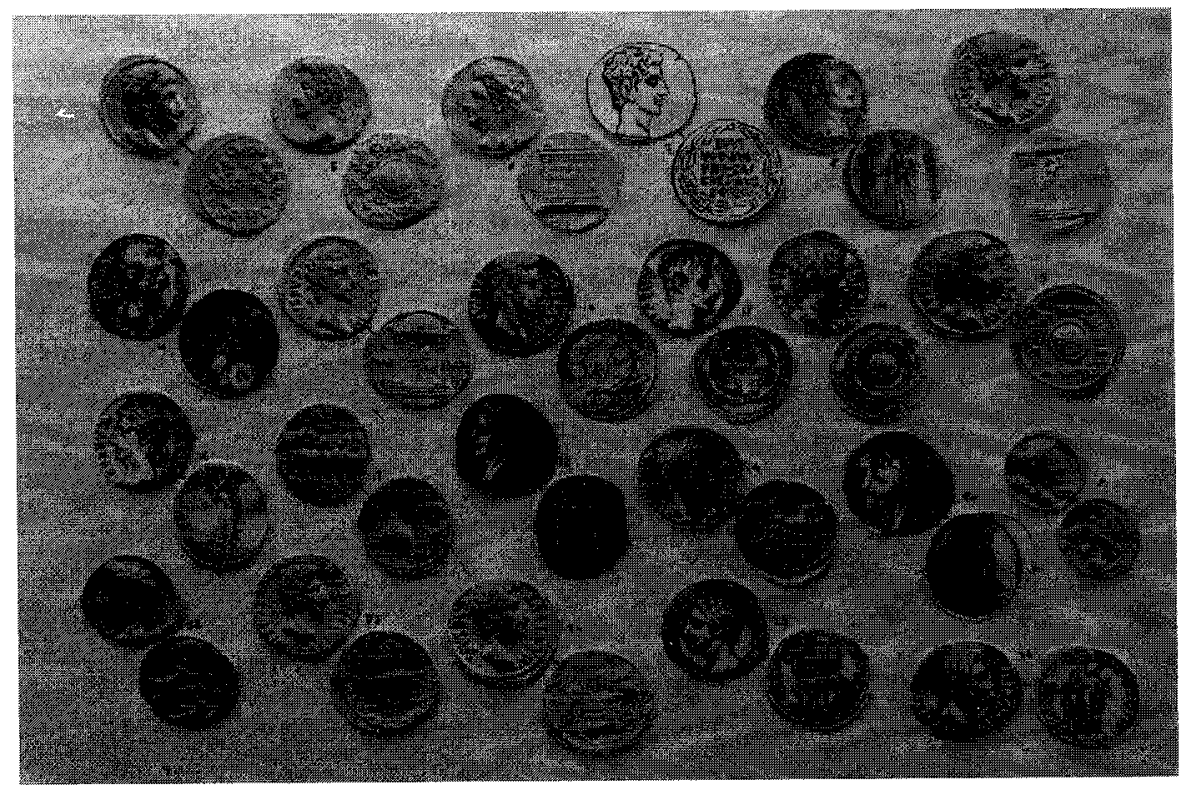

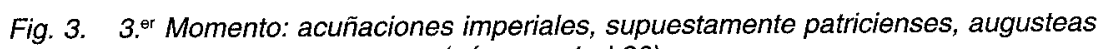
(números 4 al 26). 
con estos motivos una idea principal: la figura de Augusto, por medio de la victoria y de los homenajes a su persona; es la misma concepción que en Patricia con dos diferencias a destacar: la geográfica, que situó dos cecas estratégicamente para un fácil aprovisionamiento de amonedaciones a las tropas. Y la propagandística, pues Caesaraugusta volcó su iconografía - la cual era mas pobre en combinaciones y variantes que la de Patriciaen el tipo que representaba el Clipeo de la Virtud entregado a Augusto en los homenajes del año 27 a. C., por la carga militar que entrañaba para el príncipe (era una importante «condecoración» militar) que en ese momento intentaba cerrar la total pacificación de Hispania como logro de la Pax, sobre la que asentó los cimientos de su poder.

\section{CUARTO MOMENTO}

Una vez establecida la total pacificación de la Península lbérica, por parte de Augusto, se abre para la ceca local el último periodo de acuñaciones, las que presentan en su reverso el apelativo de la colonia: Patricia, puesto en relación con el hecho de ser la única capital de provincia hispana con rango senatorial, es decir, entregada a los Patres ${ }^{14}$. Es este momento el más rico y abundante en paralelos por lo que respecta a la ciudad. Los motivos de este momento en Hispania tienden a unirse al pleno sentido de la Romanización mediante una selección de motivos que ensalzan al propio Princeps, bien directamente por medio del culto imperial, o por medio de complicadas imágenes que tienden a dar interpretaciones múltiples -siempre en conexión al usuario-. A veces se dejan entrever tipos con resabios indígenas ( caso del empleo del Toro, en los reversos de cecas del valle del Ebro), pero que no dejan de utilizar la imagen de Augusto en los anversos. En la serie ${ }^{15}$ con leyenda COLONIA PATRICIA hemos creído ver los siguientes motivos comunes.

Cabe hacer una distinción categórica entre los paralelos que se dejan ver en las nueve cecas con tipos de reverso parangonables a las patricienses: las ciudades capitales de provincia -Emérita y Tarraco-; y las demás ciudades que coincidieron en el empleo de los tipos, aunque de estas últimas se impone hacer una especial mención a las monedas de Traducta, Ebora y Acci, por cuestiones iconográficas que con estas cecas abordaremos.

\footnotetext{
VAQUerizo, D. (Editor) (1996) Córdoba en tiempos de Séneca, Córdoba, (págs. 12-14).

t5 Un paralelo, en cuanto a serie con los mismos valores, lo vemos en las emisiones extrapenínsulares de la ceca de Achaea: RPC, 1.462-1466.
} 
Son las capitales de las provincias hispánicas de la Lusitania y la Tarraconense ricas en tipos locales Imperiales. Las series de Emérita nos muestran una amplia tirada de valores y de tipos acuñados, no sólo en el principado de Augusto, sino que perduran en el de Tiberio. Los motivos de esta ceca son un verdadero compendio de imágenes que unen a Emérita con el resto de las cecas peninsulares. Sus tipos locales son herederos de las acuñaciones primigenias a nombre de $P$. Carisius, aludidas anteriormente, para continuar con el empleo de tipos de reverso alusivos a la fundación de la colonia (yunta fundacional), alusiones a las legiones asentadas (enseñas y águilas legionarias), culto imperial (aras, templos y emperatrices.), unido todo ello al verdadero protagonista - el príncipe- que ocupa, en amplia mayoría, la cara más importante de la moneda: el Anverso.

Los puntos de unión entre las cecas de Patricia y Emérita son el empleo en los reversos de enseñas legionarias (Vives, T. IV, pág. $63\left(n^{\circ}{ }^{\circ} 30\right)$ sobre valores de semises y no de dupondios como ocurre en Patricia. Pese a que estos pequeños bronces emplean la imagen antes comentada, su significado es diferente, ya que estos motivos vienen aclarados por la leyenda $L E-V . X$. y son el homenaje de la ciudad al asentamiento de los veteranos de estas legiones en la capital lusitana; como vemos el ejemplo de

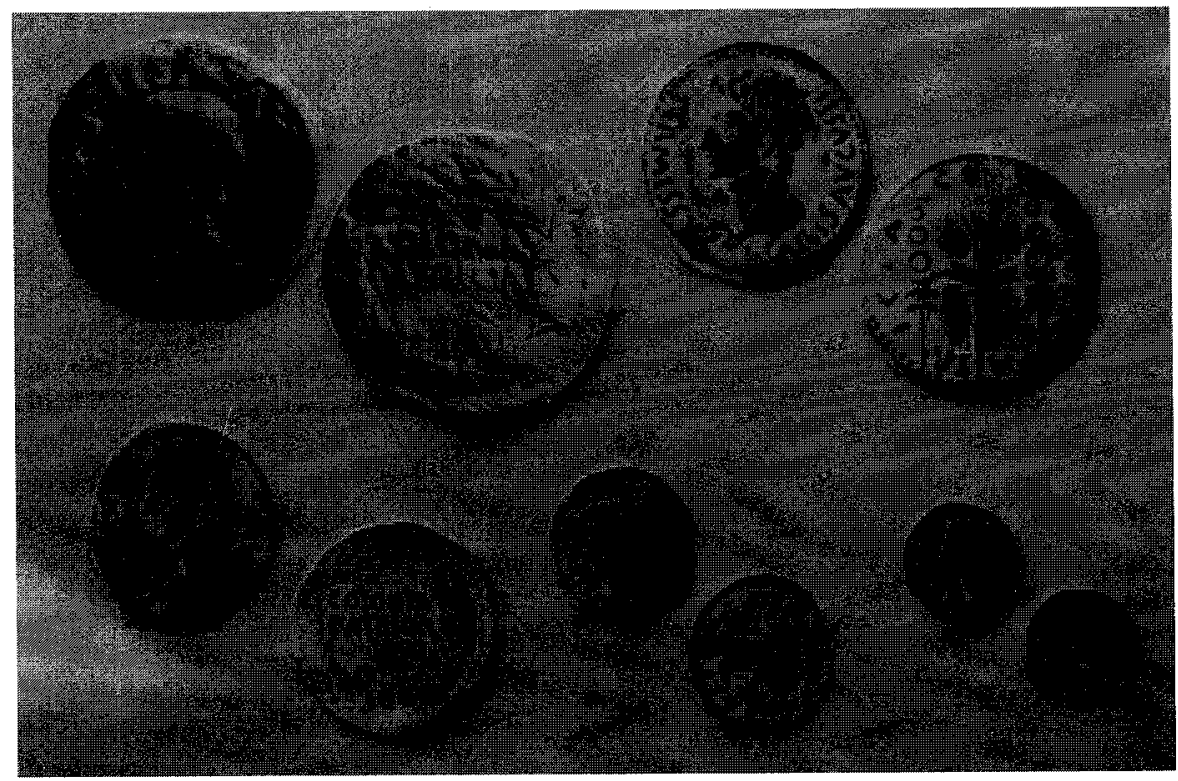

Fig. 4. $4 .^{\circ}$ Momento: serie local augustea con leyenda COLONIA PATRICIA (números 27 al 31). 
Estudio de los paralelos iconográficos en las emisiones monetales..

coincidencia de imágenes no nos dan el mismo significado, para la capital Bética, el empleo de estos tipos guarda una relación con hechos propagandísticos más cosmopolitas, frente a las intenciones más localistas de las emisiones de Mérida.

También podemos ver en las acuñaciones de la ceca Lusitana el empleo de corona cívica en cuadrantes (Vives, T. IV, pág. 64 ( . $^{\circ} 35$ ), en una pieza con alusión clara -A. / AVGUS. EME. R. / IMP.-CAES.- a la unión y al agradecimiento de la ciudad a Augusto, coincidiendo con Patricia, pero de nuevo la imagen de anverso de esta moneda conecta con una imagen particularista de la colonia: una cabeza femenina que arroja agua por la boca. Tipo tan heterodoxo no guarda relación con la ceca cordobesa y más bien se acerca a una alusión al río que cruza la ciudad y del cual se beneficiaria.

El último motivo que encontramos en ambas cecas son los instrumentos sacerdotales acuñados sobre reversos de cuadrante (Vives, T. IV, pág. $63\left(n .^{\circ} 24\right)$. De todos los paralelos encontrados, es esta pieza la que guarda mayor parecido icónico con su homónima cordobesa. Su anverso es idéntico, la leyenda del reverso - C.A.E.- es el acrónimo de la ciudad ( en Patricia es el nombre completo). La única diferencia es la colocación de los instrumentos sacerdotales La ciudad lusitana presenta: Patera, Lituus y Oenochoe. Faltándcie el aspergilum como si aparece en la ceca patriciense, además tenemos que tener presente que la disposición de los cuatro símbolos que forman el tipo no es igual. En nuestra opinión este reverso refleja el nombramiento de Augusto como Pontífice Máximo, la ceca de Emérita no quería ser ajena a este acontecimiento y por ello acuñó una moneda con este trasfondo, aunque no realizó una serie conmemorativa que fue lo que ocurrió en Patricia.

En la ceca local de Tarraco (Vives, T. IV, pág. 131-133 (n. $\left.{ }^{\circ} 7-26\right)$ ) los tipos numismáticos locales tarraconenses nos dan idea de la importancia del culto imperial ${ }^{16}$ de época tiberiana en la provincia Citerior ( empleo en grandes bronces de templos octástilos, estatuas sedentes del emperador y aras de culto) como orgullo local por haber concedido, previamente, Augusto este privilegio cultual en la ciudad. Incluso en estas acuñaciones se emplean coronas cívicas, en las cuales, se puede leer el nombre de la colonia en acrónimos - C.V.T.T.-. Pero en el principado de Octavio, que es el que nos interesa para poder tomar semejanzas

16 Gimeno, J. (1992) «Plinio, Nat. Hist. III, 3, 21,: reflexiones acerca de la capitalidad de Hispania Citerior», Latomus, 53, (39-79). 
entre cecas hispanas, sólo presentan correspondencia iconografica, estas dos cecas, en la corona cívica de reverso que Tarraco acuñó en cuadrantes (Vives, Lámina CLXIX, 7 y 8) con imágenes antropomorfas de fuerte arraigo indígena (empleo en los anversos de un toro). Lo que parece expresar esta ceca en época augustea es la sucesión imperial, para esto se utilizan las imágenes de Cayo y Lucio en la mayoría de sus monedas imitando los denarios (R.I.C., 207) acuñados en la Galia. Ante lo visto debemos plantear que las imágenes que tienen en común estas cecas no tienen la misma conexión propagandística, sino que parten de situaciones diferentes: las patricienses como homenaje a Augusto y las tarraconenses como alusión secundaria a la época, ya que los tipos ibéricos todavía se resistían a desaparecer y eran los que dominan en los cuños.

Vistas las ciudades que compartieron el privilegio de ser capitales de provincia romana, debemos considerar otras cecas que también incluyen en sus tipos monetales los motivos patricienses. Para ello se impone ordenar las ciudades emisoras en función de su respectiva localización provincial.

Las cecas de la Provincia Citerior Tarraconense son las primeras que vamos a analizar, por ser la más abundante en número. De todas ellas es Cartagonova la que mayor esplendor y tradición -productivo e iconográfico- ha dado a las emisiones antiguas hispanas. Sus series imperiales abarcan los principados de Augusto, Tiberio y Claudio, siendo el primer momento augusteo el que va a servir de paralelo inmediato a nuestro estudio. Durante el gobierno de Octavio se da en esta ceca un empleo de imágenes centradas en el culto imperial (Vives, Lám. CXXXI, n. 8,9 y 10), por aparece en sus monedas sacerdotes, instrumentos sacerdotales, animales para el culto ( toros), etc.; junto a este tema también se puede apreciar un cierto desorden tipológico, que responde a un claro dominio de prestamos de imágenes imperiales (Vives, Lám. CXXX, n. ${ }^{\circ} 1,3,5,10$ y 12. Y, Lám. CXXXI, n. ${ }^{\circ} 1,9,13,14,15$ y 17). Los puntos de contacto entre las dos cecas en estudio vienen marcados por el empleo de instrumentos sacerdotales en ases y divisores y de alusiones legionarias en los mismos valores.

En lo que respecta a los instrumentos cultuales, son en esta ceca un apoyo icónico a la importante articulación del culto imperial en la ciudad. Como antes hemos mencionado en los reversos de las monedas cartaginesas se encuentran una amplia gama de elementos: símpulo, apex, lituus, aspergilum, segur, patera, oenocoe..., como en las emisiones patricienses, pero con una carga propagandística diferente. Los abridores de cuños cartaginenses - por decisión de la magistratura local pertinente- 
idearon la manera más correcta de destacar a la ciudad, por el ortodoxo hacer en su adoración a Augusto; mientras en Patricia es más preeminente el destacar el advenimiento al pontificado máximo.

Las continuas menciones legionarias de Cartagonova (Vives, T. IV, Pág. $35, n{ }^{\circ} 10$ ) en sus series locales imperiales son el resultado de la unión entre ella y el ejercito. Para ello emplearon enseñas legionarias inspiradas en las series orientales de denarios de M. Antonio (Sydenham, n. ${ }^{\circ} 1.215$ y ss.), estos tipos tienen en nuestra opinión dos aspectos que la ceca quiere destacar: La vinculación a los ejércitos de tierra (por medio de las insignias del reverso), y la alusión a la marina imperial que recalaba en su puerto ( empleo en los anversos de naves militares). Lejana visión es la que presenta Cartagonova a la de Patricia en sus tipos militares, la primera parte de una situación marcada por una tradición secular que uso como arquetipo unas imágenes muy de moda en los años 30 del siglo । a. C., -el poderío militar de $\mathrm{M}$. Antonio en Oriente- y contrarias a las pretensiones políticas de Augusto. Las segundas son el resultado del préstamo de una imagen claramente partidaria a Augusto como máximo representante de las legiones.

Las imágenes que presenta la ceca de la Colonia Lulia Augusta llici, paralelos a Patricia son el empleo de vexilo y águila militar entre dos enseñas legionarias en los reversos de los semises (Vives, Tomo IV, pág. 41 (n. $\left.{ }^{\circ} 1\right)$ acuñados en época augustea. El motivo militar aquí empleado esta más próximo a las acuñaciones cartaginesas - de las que son análogas ${ }^{17}$ además es una alusión al asentamiento de legiones concretas en la ciudad. Por lo que tenemos un paralelo semejante a las piezas emeritenses, antes expuestas, y no al caso cordobés, que fue tradicionalmente confundido con el mensaje militar de estos motivos, los cuales fueron empleados en las emisiones de esta ceca en época tiberiana.

La ceca de Bilbilis presentó en época de Augusto una fuerte tendencia a la inclusión de tipos seculares en sus monedas. Utilizó en sus reversos el tipo de jinete ibérico y dejo los anversos para acuñar la cabeza del príncipe que reemplazaba a la histórica imagen divina - masculina y barbada- que dominó en todas las acuñaciones de la Citerior. Este cambio debió servir a los habitantes de la ciudad para comprender el Traslado de poder y la nueva dependencia de la ciudad a un estado plenamente romanizado. Pero el empleó en una moneda de la corona cívica (Vives, Tomo IV, pág. $55, n^{\circ}{ }^{\circ} 11$ ) es to que hace paralelizable ambas cecas, aunque la idea del tipo es diferente:

${ }^{17}$ Veáse VIVES, op. cit., tomo IV, pág. 39 y ss. 
en Bilbilis se incluye este motivo para unir a los magistrados locales con el régimen político imperial - representado en la moneda - ya que se enmarca la corona en el nombre del magistrado y esta a su vez encierra el cargo del individuo: / VIR. como vemos la utilización en estas cecas de la corona cívica contiene significados diferentes, esta ciudad sólo pretendió dar realce a sus magistraturas locales, frente al sentido más profundo de la corona cívica patriciense.

Dentro de las cecas hispanas locales de época augustea en el valle del Ebro, destacamos la de Turiaso por el empleo en ases de la corona cívica (Vives, T IV, Pág. 92 (7, 9, 10, y 11)). En principio podemos pensar que pueda existir una coincidencia en la utilización de los tipos con Patricia, pero saldremos de dudas una vez que observamos las leyendas que acompañan al tipo, las cuales hacen referencia a cargos municipales y a los magistrados que los ocuparon. Es por tanto un caso más acorde con la ceca de Bilbilis, antes analizada, que con la ceca de Patricia.

Un caso muy próximo ocurre en la ceca de Calagurris, donde en el reverso de los cuadrantes augusteos (Vives, T. IV, pág $99\left(n .^{\circ} 20\right)$ aparece una corona cívica enmarcando leyenda, ésta alusiva a la más alta magistratura local (Ilvir-L. Pris-Broccho) y no al homenaje que Augusto recibió en el año 27 a. C.

Como hemos comprobado en las últimas cecas de la Tarraconense, hay múltiples ejemplos de imágenes adecuadas a los propósitos locales, en los tipos que emplearon la corona cívica en los reversos. La idea que nos trasmiten es diferente a la patriciense, ya que uno de los logros de estas ciudades en esta época es la culminación del proceso de Romanización que se formó en ellas. Por esto encontramos un afán de informar a ciudadanos de otras ciudades del hecho de unir a un tipo ya consolidado - Corona Cívica-, los cargos locales de estas ciudades (Bilbilis, Turiaso y Calagurris) que ya funcionaban en ellas.

Ya en la Provincia Ulterior Bética también se producen paralelos iconograficos con la Córdoba romana, es el caso de Gades, ciudad de gran tradición acuñadora, parangonable a las orientales. En sus tipos locales, de época augustea, se emplean todavía una mezcla de tradición e imnovación: la primera representada por el empleo de la secular cabeza de Hercules y las constantes alusiones al templo del dios y a los instrumentos empleados en su culto ( Vives, Lám. LXXVII, n. ${ }^{\circ} 1,2,3$ y 4). Pero en los sestercios (Vives, Lám. LXXVII, $n .^{\circ} 5,6$ y 7 ), que emplean la cabeza de Augusto en los anversos, se reconoce la innovación de los motivos, ya que se añade a la imagen del templo el empleo de las cabezas adosadas de Cayo y Lucio y el tipo en común con Patricia, la corona civica, que adquiere en este motivo un 
respaldo del Príncipe con elementos tradicionales -el templo- y con hechos de actualidad -la sucesión imperial-. La ceca de Gades es en este momento, ateniéndonos a sus tipos, un centro receptor de las novedades políticas que sirven de arquetipos a sus acuñaciones. También se produjo en Patricia un proceso parecido, merced al carácter más receptivo de las ciudades Béticas que vino a través del intenso comercio que se practicaba desde el interior hacia el puerto gaditano hasta Roma, y viceversa, algo muy similar a lo que debió suceder en la Córdoba de finales del siglo I a. C., en cuanto a comunicación y comercio se refiere.

Los últimos paralelos con la serie patriciense (Vives, tomo IV, pág. 114) los tomamos de un grupo que formó A. Vives ${ }^{18}$ con la característica común de emplear "Corona de Laurel" enmarcando el nombre de la colonia. Las cecas a las que nos referimos son: Iulia Traducta, Ebora y Acci, junto a Patricia. Las acuñaciones de urgencia en cecas provisionales en la Península lbérica fueron el ejemplo inmediato a seguir en las acuñaciones de estas cecas, ya que los arquetipos formaron escuela y sirvieron a las ciudades de este supuesto grupo para hacer uso de ellos. Lo que sí parece factible es ver la mano de un mismo técnico en la realización de los cuños y no parece arriesgado pensar en una ceca primigenia de la que partieran, grabados los motivos, a otras ciudades y fueran acuñados en ellas.

Por lo que respecta a la ceca de lulia Traducta los tipos de anverso empleados son idénticos a los patricienses ya que se emplea la cabeza de Augusto (Vives, Lám. CLXIV, . $^{\circ} 2,3$ y 13) con leyenda PERM. CAES. $A V G$., idéntica al caso cordobés. Pero los paralelos más interesantes los encontramos en los reversos de los ases, semises y cuadrantes (Vives, Lám. CLXIV, n. ${ }^{\circ} 13,15$ y 16), los cuales si no fuera por la leyenda - Iulia-Trad.- se dirían que son patricienses. En cuanto al trasfondo de estos tipos hay que pensar que contienen la mismas ideas que en Patricia, es este un fiel apoyo a la teoría de una programación de los tipos desde fuera de la propia ciudad emisora o simplemente de un préstamo de imagen entre ciudades en el mismo momento; creemos más lógico pensar que fuese la capital provincial la ceca primigenia donde se crearan los modelos.

Para la ceca de Ébora hay que tener presente que sólo emitió valores de dupondio y as. Pero sí podemos ver que los tipos empleados son todos comunes a ambas cecas (Vives, Tomo IV, pág. 119, n. ${ }^{\circ}$, 2 y 3). Para los

18 Op. cit., Vives, tomo IV pág. 114 y ss. 
anversos se emplea la cabeza de Augusto y en la leyenda la misma permisión que en la ceca cordobesa. Los reversos de los dupondios presentan los motivos, con la misma disposición de los cuadrantes patricienses, es decir los cuatro instrumentos pontificales aunque por el mayor modulo de esta pieza se nos permite apreciar un mayor detalle de los tipos. En los reversos de los ases se empleó la corona cívica que encierra el nombre de la colonia LIBERAL-ITATIS-IVLIAE-EBOR. que siguen la misma idea formal que en Patricia, posiblemente debió gustar el esquema de los tipos entre las ciudades que recibieron de Augusto el permiso de acuñación y vincularon el agradecimiento de la ciudad a la figura del príncipe.

La última ceca que presenta una relación tipológica es la de Acci. En esta ciudad hay que matizar un poco las ideas que están detrás de los motivos ya que encontramos algunas diferencias con respecto a Patricia. Si nos limitamos a las monedas emitidas en época augustea los elementos iconograficos Accitanos no presentan parecidos con los patricienses ya que los tipos son exclusivamente referencias a las legiones asentadas, para sus acuñaciones se empleó como motivo de reverso las insignias militares (Vives, Lám. CLXVI, $n .^{\circ} 1,2$ y 3) con la correspondiente alusión a las legiones asentadas en la ciudad, esto es más parecido a las monedas emeritenses (Vives, Lám. CXLI, n. ${ }^{\circ} 7$ ) que a los tipos militares patricienses. Los motivos que en verdad guardan una relación formal con Patricia están acuñados en época tiberiana (Vives, Lám. CLXVI, n. ${ }^{\circ} 6$ y 7) y sirven para darnos idea del éxito que tuvieron la utilización de elementos pontificales y de coronas de roble enmarcando el nombre de la ciudad emisora.

Una vez terminado este recorrido a las cecas hispanas tenemos que tener presente el cambio paulatino que supuso en toda la Península Ibérica el abandono de modelos iconograficos numismáticos anteriores (griegos, fenicios e indígenas) para pasar a los eminentemente romanos. De esta transformación la ciudad de Córdoba no tiene elementos monetales para poder contrastar una evolución ya que sus tipos de sus monedas fueron genuinamente romanos desde el primeras emisiones.

Como hemos podido ver en este trabajo los paralelos para las acuñaciones numismáticas de la Córdoba romana se establecen en función de los diferentes motivos que otras cecas emitieron. En concreto para los tres primeros momentos de acuñación es inseparable de la tutela iconografica que ejercieron las monedas de la ceca de Roma, produciendo la ceca local una recopilación de imágenes prestadas. Pero para el último momento de acuñación la ceca Patriciense supo crear unos tipos que, aunque también prestados, motivaron una escuela, sirviendo de modelo para otras cecas hispanas. 
Debemos tener en cuenta que la investigación numismática en la Córdoba romana se encuentra en una fase inicial, y que, por tanto la realización de futuros estudios sobre materiales nuevos que aparezcan en el solar cordobés, o los que custodia el Museo Arqueológico y Etnológico de Córdoba, o las colecciones privadas (legalmente declaradas) pueden hacer variar esta panorámica, recordemos como todavía existen dudas sobre la fiabilidad de localización en las monedas augusteas imperiales, o incluso el hecho de que pudiera existir un quinto momento productivo, para monedas de imitación, en época del Princeps Claudio ${ }^{19}$.

19 CEBRIÁN, M.A. (1999) "Imitaciones de Claudio I en el monetario del Museo Arqueológico y Etnológico de Córdoba", Numisma 242, XLIX, págs. 7-56. 